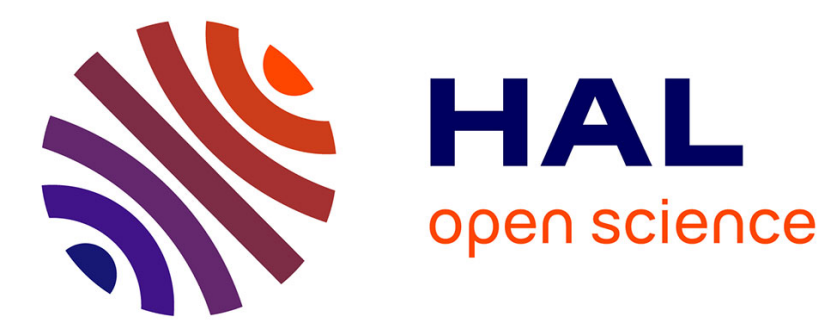

\title{
The political ecology of ecosystem services
}

Christian Kull, Xavier Arnauld de Sartre, Monica Castro

\section{To cite this version:}

Christian Kull, Xavier Arnauld de Sartre, Monica Castro. The political ecology of ecosystem services.

Geoforum, 2015, 10.1016/j.geoforum.2015.03.004 . halshs-01252581

\section{HAL Id: halshs-01252581 \\ https://shs.hal.science/halshs-01252581}

Submitted on 8 Jan 2016

HAL is a multi-disciplinary open access archive for the deposit and dissemination of scientific research documents, whether they are published or not. The documents may come from teaching and research institutions in France or abroad, or from public or private research centers.
L'archive ouverte pluridisciplinaire HAL, est destinée au dépôt et à la diffusion de documents scientifiques de niveau recherche, publiés ou non, émanant des établissements d'enseignement et de recherche français ou étrangers, des laboratoires publics ou privés. 


\title{
The political ecology of ecosystem services
}

\author{
Christian A. KULL ${ }^{\mathrm{a},{ }^{*},}$ Xavier ARNAULD DE SARTRE ${ }^{\mathrm{b}}$,MonicaCASTRO-LARRAÑAGA ${ }^{\mathrm{b}, 1}$
}

${ }^{\mathrm{a}}$ School of Geography and Environmental Science, Monash University, Melbourne, Victoria 3800, Australia

${ }^{\mathrm{b}}$ Laboratoire Société Environnement Territoire(UMR 5603 CNRS/Université de Pau),Avenue du Doyen Poplawski, 64000 Pau, France

* Corresponding author. Email :christian.kull@monash.edu

${ }^{1}$ Presentaddress: Institut de géographie et durabilité, Université de Lausanne, Mouline Géopolis, CH-1015 Lausanne, Switzerland

Highlights(3-5 bullets max 85 char each)

\begin{abstract}
(should be 250 words)
The current dominance of "ecosystem services" as a guiding concept for environmental management - where it appears as a neutral, obvious, taken-for-granted concept - hides the fact that there are choices implicit in its framing and in its application. In other words, it is a highly political concept.Following a political ecology framework, we investigate the origin and agency of the ecosystem services idea, its relationship to multi-scale power structures that constrain or facilitate certain outcomes, the practical difficulties of applying the idea, and its impacts for different parts of society and the environment.Building on the literature, on an analysis of theMillennium Ecosystem Assessment, and onbrief examples from tropical rain forest contexts such as Brazil and Madagascar, we investigate four moments or processes in the construction and application of the ecosystem services idea:discursive (the emergence of the term), ontological (what knowledge does the concept allow?), scientific (debates and difficulties in its practical application), and political (who wins, who loses?).All four components have ecological and political consequences. First, choices are made during the framing and institutionalization of the concept that mobilize, for example, a human-nature dichotomy and the pre-eminence of ecological and economic perspectives. Second, choices are made in the application of the concept, in terms of the type of service, the scale of analysis, and the kind of market rationality, that create winners and losers. The concept is a boundary object with widespread appeal, used in diverse ways by different interests to justify different kinds of interventions that at times might be totally opposed.
\end{abstract}

\section{Keywords (6)}

Ecosystem services, environmental services, market-based instruments, Brazil, Madagascar, tropical forests, REDD 


\section{Introduction}

'Ecosystem services' (ES) will be probably remembered as one of the buzzwords of environmental management at the beginning of the $21^{\text {st }}$ century. The concept directs our attention to just how much humanity depends on healthy ecosystems and ecosystem processes. We depend on the combined actions of plants, animals, soils, water, and nutrients for food production, for regulation of climate and water resources, for aesthetic and spiritual values, and for basic, underlying life-supporting processes like photosynthesis and soil formation. Given that human transformations of the world's ecosystems have been more rapid and extensive in the past century than they have ever been before, scientists, policymakers, and practitioners have used the concept to justify a wide array of environmental initiatives (Costanza et al., 1997a; Daily et al., 1997; MEA, 2005; Kumar, 2012).

Its crowning moment was its popularization and formalization in the 2005 Millennium Ecosystem Assessment, a report sponsored by a who's who of international environmental agencies (MEA, 2005). The MEA framed its assessment of the dramatichuman-caused changes to the environment in terms of the damage to ES. Current use of the ES idea demonstrates a tight conformity of definition. ${ }^{1}$ It is centered on four main elements:

- something out there (ecosystems, nature, forests, watersheds...)

- provides things (resources, goods, products, services...)

- useful to people and nature (health, livelihoods, fundamental life-support systems...)

- and this should be valued (often in monetary terms).

These 'useful things to be valued' tend to be divided into four main categories.Regulating services are the benefits gained from regulating ecosystem processes, such as air quality, climate, water, erosion, waste, diseases, pests, pollination, and hazards. Provisioning services are the direct products we obtain from ecosystems, like food, fiber, fuel, and water. Cultural services are non-material, such as education, spiritual values, and recreation. Supporting services are the indirect or long-term processes that are necessary for the production of the previous three categories of service, like soil formation, photosynthesis, and nutrient cycling (MEA, 2005, p. 40).

\footnotetext{
${ }^{1}$ The definitions were accessed from diverse publications and agency websites. Our assertion of tight conformity constrasts with Nahlik et al. (2012), Fisher et al. (2009), and Boyd and Banzhaf (2007) who highlight disagreement over the definitions.
} 
The ES concept has gained impressive rhetorical and scientific power in the last decade or two, rising to the very pinnacle of multi-national scientific and policy circles. The journal Ecological Economics alone has 237 articles with the term "ecosystem services" in the title or abstract $^{2}$, and publisher Elsevier launched a journal titled Ecosystem Services in 2012. Following the MEA, the British government launched a $£ 40 \mathrm{~m}$ research program linking its development agency (DFID) and its national science agencies (NERC and ESRC), titled Ecosystem services for poverty alleviation. Both an applied and critical literature has accumulated nearly as fast as the concept itself. On the one hand, many practitioners and scholars seek ways to operationalize the concept, apply it in particular case studies, or frame their arguments with it. Some attempt to better circumscribe definitions and tools to be able to use the concept in economic models (e.g. Fischer et al., 2009; Johnston and Russell, 2011). Others analyze the loss or degradation of ES (e.g. Lant et al. 2008), or seek to work out the mechanisms by which payments for ES can be implemented (e.g. The Economics of Ecosystems and Biodiversity initiative, $\mathrm{TEEB}^{3}$ ).

On the other hand, a variety of scholars critique the ES concept from both internal and external perspectives.From an ecological perspective, the concept is criticized for obscuring ecological functions (Peterson, 2009)or leading to unjustified simplifications (Norgaard, 2010; Swift et al., 2004).From a strategic perspective, some see the concept as too broad, easily confused with others (Lamarque et al., 2011), while others critique its political efficacy (Van Hecken, 2010). Finally, from a social perspective, scholars critique the way in which the concept avoids consideration of crucial social, political and contextual factors (Corbera et al., 2007; Daw et al., 2011; Fairhead et al., 2012). Furthermore, scholars critique the way in which the concept reflects and promotes certain market-based models of society. For instance, Gomez-Baggethum et al. (2010) argue that even if the idea in itself has merit, its reinforcement of a neoclassical economic model reproduces the market logic and its underlying ideology.Similarly, critical scholars criticize ES as one tool in a quiver of neoliberal approaches to the environment that commodify nature and create new sites for capital accumulation largely in the hands of a global elite (Heynen and Robbins, 2005; McAfee, 1999, 2012a, b; McCarthy and Prudham, 2004).

\footnotetext{
${ }^{2}$ As of 21 August, 2013 (search performed via www.sciencedirect.com)

${ }^{3}$ www.teebweb.org, accessed 21 Aug. 2013
} 
Concern over environmental transformations and environmental protection long precedes 'ecosystem services'. And ES is only one out of many possible ways of framing environmentsociety relationships. This begs a number of questions. What explains its meteoric rise as a primary tool to think about environment-society relations? What does it reflect about today's society? What are its advantages and disadvantages? Who gains from it, who loses? Is it an indispensable tool to save nature in the modern world, a further appropriation of nature by capital, or something else altogether? In this article, we seek to build a bridge between social science critiques and the ways in which practitioners have used the concept. We seek to understand more specifically how the notion works, how it is used and misused, what the notion allows and does not allow, and what its impacts are. As these objectives specifically engage with winners and losers in terms of environmental management, the power structures and discursive frameworks that facilitate such outcomes, and the specific regional ecological and social contexts in which the concept is used, we have labeled our approach a "political ecology" of ES.We argue that the utility of the ES concept depends on the arena where it is used and what it is used for.

\section{Approach: theory and method}

What do we mean by 'doing a political ecology of ecosystem services'? We do so in the sense that political ecology is a research approach or posture that addresses nature-society phenomena - whether concrete local cases of environmental change or abstract global concepts like ES - in a particular way. Using historically and geographically contextual approaches, political ecology guides researchers to pay attention not only to the 'ecology' or science of the topic at hand, but also to the agency of ideas and the actions of social, economic, and discursive power across scales. The approach pays particular attention to who wins, who loses, and what the impacts are for different parts of society and different components of the environment (Robbins, 2012; Gautier and Benjaminsen, 2012). In the words of Tim Forsyth (2005, p. 165), who applied the approach to investigate the 'ecosystem approach' idea, political ecology "does not suggest that environmental problems do not exist, or that ecological science cannot help, but acknowledges the greater political controversies about the nature of ecological risk, and the influence of different political actors upon what is seen to be authoritative knowledge." It differs from apolitical approaches to understanding environment-society concepts, like Timothy Farnham's history of 'biological diversity' in which the success of the concept is largely ascribed to the term itself: its breadth, engulfing "a 
range of values and concerns that were previously scattered disparately throughout the scientific and conservation communities", and the fact that it "struck a chord with those both inside and outside the traditional conservation community" (2007, p. 5-6).

Political ecologists have already produced a number of critical analyses that touch, in one way or another, on theES concept. The main critics investigateES as a tool of a neoliberal conservation, of market-based environmental policy, or as a project of 'green grabbing' that creates new markets and empowers new actors (Arsel and Büscher, 2012; Fairhead et al. 2012; Bumpus and Liverman, 2012; MacDonald and Corson, 2012). EScan reinforce unequal power relationships (Corbrera et al., 2007) or lead to social injustice (Daw et al., 2001; MacAfee, 2012a). While the ES concept did not imply such outcomes, its use in the particular political and economic situations of recent decades conditioned these outcomes (GómezBaggethun et al., 2010; Gómez-Baggethun and Ruiz-Perez, 2011). Therefore, political ecologists have, among others, shown that the metrics used for such services lay on instable values and uncertainties that compromise the possibility of the commodification of nature on stable metrics (Robertson, 2006; Barnaud, 2010; Ernston and Sörling, 2012).

Nevertheless, some of the above authors, and several others, suggest that theseare not default characteristics of ES, and that the use of ES does not necessarily signal adherence to an ideology of 'neoliberalisation of nature' (reference). First of all, green neoliberalism as conceptual framework has numerous fragilities: it is not a single project, neither applicable to all kind of resources; nature itself is a word used to apply to many dimensions of biophysical world (Bakker, 2012). This means that ES cannot enroll nature so easily. Many political ecologists have shown that ES policies are very heterogeneous. In many cases, they are mostly used by States to reinforce their environmental agendas without allowing new directions in such policies (Roth and Dressler, 2012; McElwee, 2012), so that policies and practices around the ES concept deviate considerably from neoliberal doctrine (Dempsey and Roberston, 2012).Our review supports the argument that ES as a concept and tool is more complex than it has been argued in many neoliberal nature theorizations. For us, this is not only due to the nature of nature or to the nature of capitalism, but to the very notion itself, which has been marked, since its creation, by many debates among ecologists, economists, and policy makers. 
In the present piece, we seek political ecological inspiration for a more broad-scale, conceptual review of ES as a particular idea, discourse, social phenomena, and management tool. Because the object of our study is an idea or concept, we must necessarily begin in the realm of language and discourse. By deconstructing the concept, we can ask questions about where it comes from, how it has power, what it does, and whom it serves (Peetand Watts, 1996; Demeritt, 2001, 2002). Critical deconstruction examines the intellectual and institutional roots of discourses such as rainforest colonization, climate change mitigation, or protected area conservation, the conceptions of science and reality that they represent, and the ways in which they are enrolled in the exercise of power between different kinds of actors (Castro and Ollivier, 2012;Ferguson, 1994; Forsyth, 2003).Echoing Demeritt's (2001, 2002) work on global warming, we find it useful to distinguish between four types of processes in the construction of concepts like ES: discursive, ontological, scientific, andpolitical. Each reflects a different process, and a different question, that contributes to the overall aim of this review. We review each in turn - the questions it asks and the methods we will use.

\subsection{Discourse}

First, we ask how the discourse of ES emerged and rose to prominence - what socialpolitical-environmental climate created the concept. This builds on political ecology's tradition of geographically and historically situating diverse ideas like 'degradation' or 'the suburban lawn' (Leach and Mearns, 1996; Robbins, 2007). We complement these historical, analytic, and largely narrative-based approaches with analyses of the co-production of science and politics through specific networks of power and knowledge. To highlight the importance of certain networks of scientists and practitioners, we draw on bibliometric approaches (Castro and Ollivier, 2012; Xu and Marinova, 2013).

\subsection{Ontology}

Second, we take a closer look at what the concept itself consists of, asking how the notion ES works, or what the idea allows and does not allow. This part of our approach investigates how ES reflect - or even shape - our social world. Now that the concept exists, what does it suggest can be known about the world, what is its ontology? How does it frame the world and the possibilities of action? Here we build on a rich tradition of dissection of concepts as basic as 'nature' (Castree and Braun, 2001; Cronon, 1996) by analyzing ES as a type of metaphor that communicates certain ideas about human-environment relationships (Larson 2011). 


\subsection{Science}

Third, we ask how ES works, not ontologically, but in terms of the specific practicalities of application in particular contexts. This section builds on political ecology's tradition of robust attention to the ecology and science of a topic, as well as to the co-production of that science by multiple actors with different interests. Paul Robbins (2001), for example, investigates the ecology (invasive mesquite trees), the science (remote sensing land cover classifications), and the politics (farmers versus foresters) of how land is classified and managed in Rajastan. In this portion of our review, we build on the literature and our experiencescontributing to a projectidentifying and quantifyingES from 51 farms in six localities in two Amazonian frontiers -southeastern Brazil and the Andean piedmont of Colombia (Grimaldi et al., 2013). The processes behind this research illustrates the many choices implicit in the application of ES as a tool - in terms of categorization, weighting, scale, and quantifiability. These choices leave gaping holes for politics to enter (Rangan and Kull 2009).

\subsection{Politics}

Finally, we ask about the impacts of ES idea. Who are the winners, who are the losers, who uses the idea and for what purposes? A variety of political ecologists have traced the political lives of particular ideas. Peluso and Vandergeest (2001) show how the state definition of 'forest' in Southeast Asia served governments in asserting control over resources. Arnauld de Sartre and Berdoulay (2011) investigate how the idea of 'sustainable development' has specifically played out across multiple scales in the rough-and-tumble politics ofBrazilian Amazon.Political ecologists have harnessed a 'governmentality approach' that investigates how societies are rendered governable through discourses and other techniques (Agrawal, 2005; Dressler, 2013). This approach problematizes straightforward conceptions of governance and the tools it uses (like ES). It permits us to articulate local practices of power to those of high-level institutions. The approach does not allow simply being 'for' or 'against' certain ideologies or technologies of power (ES could be read as such an ideology), but instead promotes the investigation ofhow they produce effects that have meaning and consequences. The result is that we are able to grasp the rules of the discourse, to observe the power relations of policy making, and to highlight gaps between the rhetoric and practice of policy (Barry et al., 1996).In this section, we build on the literature and on brief case studies in Madagascar and Brazil to investigate who gains and who does not, or the impacts and opportunities created by the concept in a complex, multi-scalar world of social interactions. 
In sum, what we intend to do in this review is to present a critical framework and engaged political ecology of the concept of ES as an idea and governance tool. Human-environment relationships are highly diverse across and within societies. As a result, when a metaphor such as ES takes on global importance, it is necessary to deconstruct it and demonstrate the relativity of its point of view. But if we aim to balance the "hatchet and the seed" of political ecology (Robbins 2012; Batterbury and Horowitz 2013), such an approach has to take into account the conflictual contexts in which such notions are discussed, and the real-life situations where the notion is mobilized by different actors.Below, we present our review following the four categories described above.

\section{Emergence of a discourse}

The idea of ES took wings in the late 1990s with emblematic publications by high-profile ecologists and economists.Costanza et al. (1997b, p. 254) wrote in Nature that "Ecosystem goods (such as food) and services (such as waste assimilation) represent the benefits human populations derive, directly or indirectly, from ecosystem functions."Gretchen Daily (1997) edited a book published by Island Press titled Nature's Services: Societal Dependence on Natural Ecosystems, with chapters contributed by a host of influential scientists including Paul Ehrlich, Peter Vitousek, Harold Mooney, and Norman Myers. What environmental, ideological, and social contexts facilitated the emergence of this concept? Concepts like ES emerge in particular discursive and institutional spaces, in particular historical moments, and gain importance due to particular convergences of events, interests, and power structures. Here we explain the emergence of ES, exploring why it became a 'buzzword' (Callicott et al. 1999).

The ideas that constitute ES, of course, have a deep history in a variety of intellectual trends linking environment and the economy (Gómez-Baggethun et al., 2010; Gómez-Baggethun and Ruiz, 2011), particularly in the fields of environmental and ecological economics (Pearce, 1993; Costanza et al., 1997a).The concept responds to environmental crises of degradation, pollution, deforestation, and habitat loss that have be occurring for decades - as the Millennium Ecosystem Assessment notes, “over the past 50 years, humans have changed ecosystems more rapidly and extensively than in any comparable period of time in human history" (MEA, 2005, p. 1). It has also been pointed for quite some time that these crises are 
pushed largely by an economic system of unsustainable exploitation that did not, in its terms, ‘internalize its externalities’ (Pigou, 1920).

Clearly, then, the emergence of ES in the late 1990s is neither a direct response to the environmental crisis nor a profoundly new idea. Instead, its emergence reflects two broader social and political trends. The first is the growing dominance of neoliberal ideas, what Peet and Watts (1996, p.1) call 'market triumphalism'. In contrast to earlier emphases on state environmental regulation and command-and-control economics, from the Reagan-Thatcher era onwards a series of strong ideological currents supported markets as the most efficient management and regulatory tool (Brenner et al. 2010). These currents manifested in nearly every sector of governance and in most countries around the world. The second trend is captured under 'ecological modernization'. This set of ideas is based on a recognition that the environmental crisis is caused by modernization and industrialization. However, instead of using this finding to critique modernization and industrialization, it sees the solution in more and better modernization, with an attendant modernist faith in technology and in the market mechanisms of capitalism (Buttel, 2000; Mol et al., 2009). Its spirit is evident in important documents like the 1987 Brundtland Commission report that launched the idea of sustainable development, later enshrined in the 1992 Earth Summit.

As mutually reinforcing dominant discourses of the 1990s, neoliberalism and ecological modernization made it possible to conceive of society-environment relationships in a particular way. They prepared the way for it to appear quite natural that we should value, and perhaps pay for, 'services' rendered by ecosystems. A pioneering application of these ideas was in Costa Rica, a country marked by a strong uptake of neoliberal policies and environmental action: its innovative 'payments for environmental services' program was launched in 1997 (Zbinden and Lee, 2005). By why, still, did ES rise to such prominence in the way it did? To uncover the more specific process, one must investigate the networks of scientists and policy makers who promoted it.

The history of ESillustrates the role of scientific communities in the construction of 'unifying' political concepts. The emergence of the concept is strongly rooted in the work of influential academics with high-level networks. Interestingly, a number of key actors have roots that trace back to biology programs at the University of Florida (where H. T. Odum and C. S. Holling were pioneers of systems ecology) and Stanford University (home to influential 
environmentalist Paul Ehrlich). Robert Costanza, a key figure in ecological economics, studied under Odum; Gretchen Daily and contributors to her 1997 volume Peter Vitousek, Harold Mooney, Stephen Schneider were all at Stanford. Links between these and other actors were built through, among other things, meetings facilitated by the Pew Charitable Trust and the Beijer Institute of Ecological Economics in Stockholm. The latter institute, headed by Carl Folke, lists Daily, Ehrlich, and Holling and other prominent figures as fellows, and overlaps significantly with the efforts of the Resilience Alliance. Costanza's 1997 piece emerged after a workshop at the National Center for Environmental Synthesis and Analysis, NCEAS.

Within a few years of the 'seminal' publications of 1997, ES was prominently enshrined in the report of the Millennium Ecosystem Assessment (MEA, 2005). The assessment, which took place from 2001 to 2005, was conducted as a formal effort to gather knowledge and data to render an actionable package to policy makers - in a fashion similar to the IPCC climate reports or other global environmental assessments (Mitchell et al., 2006). It involved more than 1360 authors, and resulted in a theoretical framework and five volumes about the state of world's ecosystems. The process behind the MEA are highly social and structured and thus of interest in understanding how knowledge is created and promoted (Mitchell et al., 2006).

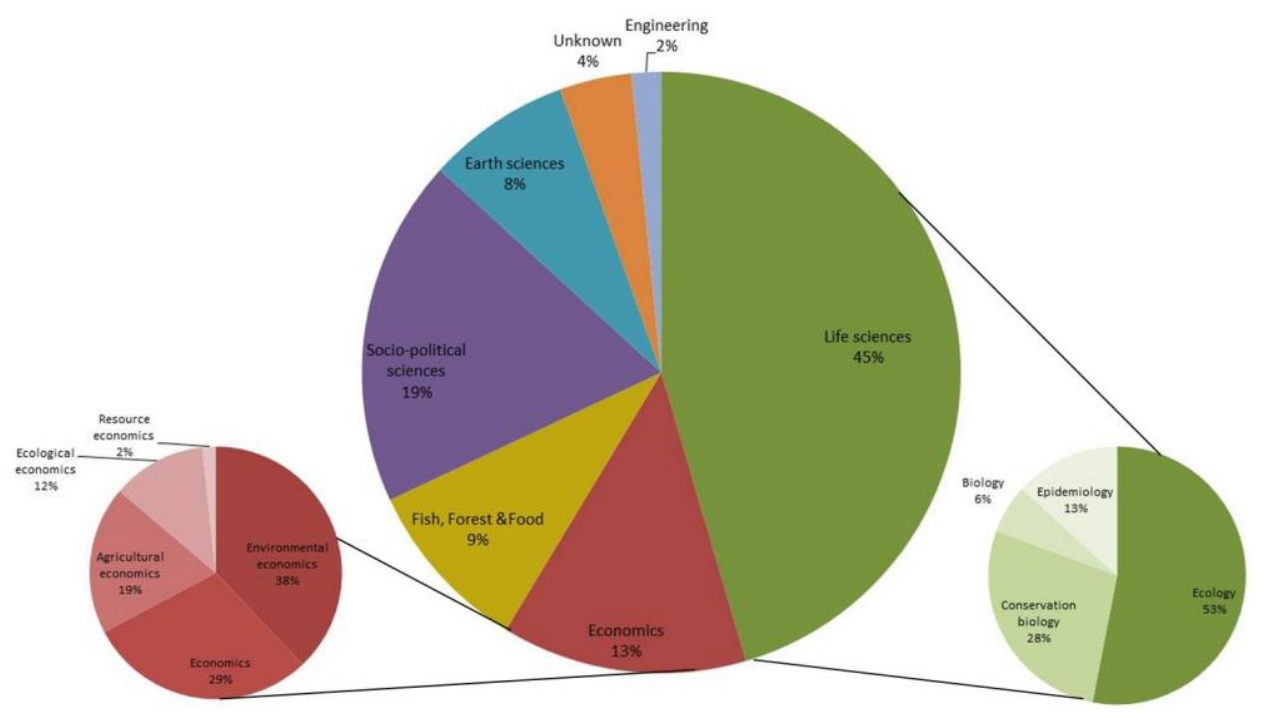

Figure 1. Disciplinary background of thelead authors of the Millennium Ecosystem Assessment (including coordinating lead authors and authors of the theoretical framework; $\mathrm{n}=534)$ 
To uncover some of these social processes, we analyzed the authors, institutional affiliations, and citations referenced in the MEA. At a general level, the authorship is unsurprising (Figure 1). Lead authors represent a wide variety of disciplines, with nearly half from biology/ecology, as would be expected given the topic matter. More striking is the prominent position of the networks of authors cited earlier, associated with Stanford University, the Beijer Institute, and the Resilience Alliance, representing a strong interest in applied ecology and the ideas of ecological economics. They appear strongly in the core of 73 who undertook the leadership of the report. ${ }^{4}$ Some of them played a role as key mediators, being part of the Board and the core writing team. These include the pioneers of the ES term (e.g. Stanford's Mooney and Daily) and of the idea of 'payment for ecosystem services' (ParthaDasgupta at Oxford), as well as specialists in managing and undertaking global assessment (Robert Watson of the World Bank, Walter Reid of Stanford).As well, a high proportion of authors cited in the report have links to Stanford, the Beijer Institute, and/or the Resilience Alliance. ${ }^{5}$ A similar dominance of citations is found in the broader scientific literature (Table $1)$.

Table 1. Top 30 authors in the scientific literature on ecosystem services.Sources: record counts based on Web of Science search for topic "Ecosystem* service*" from 1991 to 2013.The column 'scientific network/school of thought' is based on authors' affiliation (past or present) to identified institutions or projects, or 5+ publications co-authored with people from those institutions, or 5+ publications with keyword (like resilience).

\begin{tabular}{|l|c|l|l|}
\hline \multicolumn{1}{|c|}{ Authors } & Record count & \multicolumn{1}{|c|}{ Discipline } & Scientific network/School of thought \\
\hline COSTANZA R & 48 & Ecological Economics & Beijer Institute of Ecological Economics \\
\hline TSCHARNTKE T & 45 & Biology & Resilience thinking \\
\hline KREMEN C & 39 & Conservation Biology & $\begin{array}{l}\text { Beijer Institute of Ecological } \\
\text { Economics/Resilience thinking }\end{array}$ \\
\hline FOLKE C & 37 & Ecology & $\begin{array}{l}\text { Beijer Institute of Ecological } \\
\text { Economics/Resilience Alliance }\end{array}$ \\
\hline STEFFAN-DEWENTER I & 33 & Ecology & \\
\hline DAILY GC & 31 & Ecology & $\begin{array}{l}\text { Stanford/Natural capital } \\
\text { project/Resilience thinking }\end{array}$ \\
\hline KLEIN AM & 31 & Ecology & Resilience thinking (?) \\
\hline POLASKY S & 30 & Ecological Economics & Resilience thinking \\
\hline REYERS B & 27 & Conservation Biology & \\
\hline
\end{tabular}

\footnotetext{
${ }^{4}$ The number 73 represents those people who were authors or panel members involved in a minimum of three chapters or documents. Pesche (2011), using different criteria, arrives at a smaller number.

${ }^{5}$ C.f. Pesche (2011). The most frequent citations in the MEA are to international institutions (and previous highprofile reports and agendas) as well as to fisheries science (fisheries were one of the earliest domains for the melding of ecological and economic research).
} 


\begin{tabular}{|l|l|l|l|}
\hline GASTON KJ & 24 & Ecology & \\
\hline POTTS SG & 24 & Conservation Biology & \\
\hline CARPENTER SR & 22 & Ecology & $\begin{array}{l}\text { Beijer Institute of Ecological } \\
\text { Economics/Resilience Alliance }\end{array}$ \\
\hline LE MAITRE DC & 21 & Ecology & \\
\hline PERRINGS C & 21 & Ecological Economics & $\begin{array}{l}\text { Beijer Institute of Ecological } \\
\text { Economics/Resilience Alliance }\end{array}$ \\
\hline VAN WILGEN BW & 21 & Biology (botany) & \\
\hline CAIRNS J & 19 & Biology & \\
\hline CUNNINGHAM SA & 19 & Ecology & \\
\hline LAVOREL S & 19 & Ecology & Resilience thinking (?) \\
\hline TURNER RK & 19 & Ecological Economics & Resilience thinking \\
\hline ARMSWORTH PR & 18 & Ecology & Stanford/Natural Capital Project \\
\hline EHRLICH PR & 18 & Conservation Biology & Stanford \\
\hline ELMQVIST T & 18 & $\begin{array}{l}\text { Ecology (?) (Natural } \\
\text { resource management) }\end{array}$ & Stockholm Resilience Centre \\
\hline RICHARDSON DM & 18 & Ecology & \\
\hline BALMFORD A & 17 & Conservation biology & \\
\hline BOMMARCO R & 17 & Ecology & \\
\hline BRYAN BA & 17 & Geography & Natural Capital Project \\
\hline HALPERN BS & 17 & Ecology & Stanford/Natural Capital Project \\
\hline MOONEY HA & 17 & Ecology & \\
\hline O'FARRELL PJ & 17 & Ecology & \\
\hline
\end{tabular}

At the risk of simplification, what we have seen in this section is how a strong network of influential and ecologically-oriented scientists, with a long tradition of seeking to make a difference in the management of this planet and working within the frameworks of neoliberalism so dominant in the late 1990s and early 2000s, came together to propose and promote ES as a key concept for environmental management. The concept served as a 'boundary object', repackaging environmental concerns in a way that aligned with the anthropocentric and neoliberal tendencies of policy makers, and quickly gained wings. In the next section, we further investigate the ES as a boundary object, asking what it actually means.

\section{Ontology: what does the concept consist of and do?}

'Ecosystem services' is, in many ways, the newest name for 'nature'. Like 'biodiversity', which was the rallying cry for conservation biology in the 1980s and 1990s, ES implies not just a specific aspect of nature - its diversity or its services - but also serves as a label for 
nature in its entirety and stands for concerns over human damage to the environment ${ }^{6}$. Yet each of these terms, and the ways they are constructed, implies particular outlooks on nature, specific frameworks for how we are to consider life on earth and our impact on it. While the use of 'biological diversity' was an extension of conservation, representing "the natural world as a repository of environmental values" including scientific, moral, ethical, and utilitarian (Farnham, 2007, p. 3; Wilson 1988), ES more strongly emphasizes market values.

The concept ES frames the world in a particular way, implies a particular ontology (or what can be known). One way of seeing this is by analyzing it as a metaphor. ES is, at its root, a metaphor, a bunch of words that - in drawing on diverse meanings - helps us as humans communicate about the complex world (Larson, 2011, Norgaard, 2010, Tassin and Kull, 2013). Applying a term or phrase to something to which it is not literally applicable in order to suggest a resemblance, a metaphor brings together different orders of reality whose links can not be demonstrated rationally. But it also carries certain values, and allows us to go in certain directions, but not others, in effect providing a frame that can structure thought and action (Goffman, 1974). In this section, we analyze the ontology of ES through its two component metaphors, ecosystems and services, pointing out the baggage they carry. Furthermore, we point out how this double metaphor, in the neoliberal context of the 1990s and 2000s evoked in the previous section, served as a boundary object that could accommodate multiple interests.

\subsection{The 'ecosystem' metaphor}

The term 'ecosystem' tends to be used, in both scientific and public discourse, to refer to abstract assemblages of species and their environment, and the processes by which they interact. A forest may be called an ecosystem; so too a stream or a pile of cow dung. An ecosystem is a concept for analysis, not a tangible thing. Arising together with broader systems thinking, the idea is freighted with a historical analogy to an interacting, selfcontained, self-perpetuating machine. Some have criticized it for being an inappropriate term for metastable adaptive systems (O’Neill, 2001), though, arguably, the term has evolved along with conceptions of it.

\footnotetext{
${ }^{6}$ On biodiversity, see Farnham (2007).The MEA defines biodiversity as "the foundation of ecosystem services to which human well-being is intimately linked" (2005b, p. 18).
} 
A fundamental tension in the 'ecosystem' metaphor is the conceptual baggage associating it with 'nature' and natural systems, or with contexts where humans play a minor role at best. The images given in scientific discourse (textbooks, presentations, articles) tend to associate 'ecosystems' with forests, lakes, deserts, and other 'natural' areas, and feel the need to add the qualifier 'urban' or 'agro-' when specifying those places with an obvious human imprint. In popular use, the concept evokes the agency and processes of a non-human nature, permitting for instance the comment "whoa, there is a whole ecosystem in there" when staring into the refrigerator at a container of long-forgotten, moldy leftovers.

There is a tension, then, between ecosystems representing 'external' nature, the unmediated material world out there, and 'universal' nature, the all-encompassing nature of which humans are a part (Williams, 1983; Ginn and Demeritt, 2009). This is ironic, for one of the reasons conservation biologists adopted ES as a term was no doubt due to the effects of long-standing critiques of the ideas of pure nature, or the ideas of nature as an entity separate from humans. According to Callicott et al. (1999), ES represents a functionalist conservation philosophy where humans are part of nature, as opposed to a compositionalist conservation philosophy where humans are separate from it.

A consequence of this tension is that the concept 'ecosystem' only uncomfortably accommodates anthropogenic assemblages of species and their environment, such as agricultural landscapes. This is because they are not abstract assemblages running themselves, but instead very tangible entities (fields and farms) actively managed or guided by farmers, and with particular histories (Tassin, 2012). So while official definitions and schematic descriptions of ES are at pains to include anthropogenic nature - food crops from agricultural fields feature prominently among provisioning services, for example ${ }^{7}-$ the value of ES to biologists is more frequently seen as justifying conservation of natural areas (e.g. Wendland et al. 2010); the value of food crops is self-evident, after all.

\subsection{The 'services' metaphor}

The second half of ES is another metaphor. 'Service' can be understood in several ways - as the condition of serving a master, as an altruistic action, or, in an economic sense as an

\footnotetext{
${ }^{7}$ See e.g. the World Resources Institute's definition at http://pdf.wri.org/esrdefinitionsofecosystemservices.pdf (accessed 7 June 2012). Likewise, the MEA sees the scope of biodiversity extending to "all ecosystems managed and unmanaged: wildlands, nature preserves or national parks...; plantations, farms, croplands, aquaculture sites, rangelands or even urban parks and urban ecosystems" (MEA, 2005b, p. 18)
} 
activity one pays for. The latter services are transactional - there is a service rendered, and something is given back in exchange. This is the meaning evoked in ES, though there are echoes of the other sense. In the meeting of economics and ecology that created the concept, the motivational idea was the internalization of the externalities of economic production and consumption (Costanza et al., 1997b; Daily, 1997).Costanza et al. (1997b, p. 253) explicitly referred to "goods and services" and only dropped the word goods from ecosystem services "for simplicity."

The reduction of human interactions with ecosystems to a transaction (usually paid for) occludes other types of interactions. These could be experiential, spiritual, or based on other metaphors like‘stewardship' or 'living with' (Turnhout et al., 2013). It is utilitarian and anthropocentric, which is only one way of looking at the world, and which has social consequences. In particular, political ecologists have built strong critiques of how economic conceptions of nature - its commodification or reduction to financial values - abstract nature from its spatial and social contexts, enters it into capitalist relationships, and conceals or legitimates the social relations involved in its production (Castree, 2008; Ginn and Demeritt, 2009; McAfee, 1999, 2012a, b).

\subsection{Common notions and boundary discourses}

Successful concepts tend to take root because they can semantically and discursively create points of consensus. Debates about the environment tend to be highly conflictual: discussions about the mitigation of climate change, the colonization of a rainforest, or the declaration of a protected area oppose different kinds of actors and different conception of science and reality (Forsyth, 2003). In the face of such conflict, a successful concept must, at a minimum, allow a discussion between opposed interests and facilitate arbitration.Such 'boundary objects' carry widespread appeal, help translate between different interest groups, but can be used for different purposes by different actors. They are both, in the words of Star and Griesemer $(1989,393)$ "plastic enough to adapt to local needs and the constraints of the several parties employing them, yet robust enough to maintain a common identity across sites". This lies behind the strength and endurance of buzzwords like 'sustainable development' (Kates et al. 2005; Lele, 1991), 'watershed management' (Cohen, 2012), and'biological diversity' (Farnham, 2007). 
ES is also a boundary object, a successful buzzword. Its strength comes from quickly making sense to those who hear it, even though their interpretations may be varied. It combines conservation concerns over forests, wetlands, and other components of 'nature', the economic logic of a capitalism that aspires to be greener, and development interests in human wellbeing. So, while the term is really an oxymoron (it combines one concept, ecosystems, that evokes the non-human world, or at least non-human agency, and a second concept that is purely an artefact of the human world, the market for goods and services), it rose to prominence as a concept that both environmentalists and economists could find shared interest in. Environmentalists see ES as a means to find sustainable funding mechanisms for conservation actions; economists see ES as a way to incorporate externalities; policy makers see it as a convenient tool.

The concept even serves as a 'boundary object' between different schools of thought within economics. For environmental economists, it is assumed that nature (or ecosystems) is a tool of production and that its destruction is due to the externalization of the damages caused to nature by development. Nature can, from this point of view, be reinternalized in the development process if a value is given to it - if the destroyers pay for destruction of nature while conservationist receive payments, e.g. through ES. The value of nature can, then, be estimated through the calculus of its marginal contribution to richness. On the contrary, ecological economics consider that nature is not external to economy, but that economy is a subsystem of the natural system. For this reason, an ecosystem is always unique and cannot. Ecosystems provide services for humanity, but these services can only be furnished by ecosystems as a whole, and are not necessarily calculable through individual components. So, while environmental economists and ecological economists bring different conceptions to the table - reflecting a contrast between 'external' and 'universal' nature evoked earlier (Williams, 1983; Ginn and Demeritt, 2009) -they seem to have both found common cause in the ES concept (Gómez-Baggethun et al., 2010) even if their conception of how to protect these services are deeply different.

In conclusion, we have seen in this sectionthat the 'ecosystem' metaphor hides tensions between external and universal visions of nature, that the 'services' metaphor implies a certain framing of society-environment relationship, and that together they have succeeded in building bridges between conservationists, policy makers, and different economic schools of thought. The usefulness of ES as a boundary object is that it brings diverse audiences 
together; its challenges are that it hides unresolved conflicts. For instance much writing on ESuncritically conflates values, benefits, and services (Chan et al. 2012).

The apparent consensus behind terms like ES is more than simply being an attractive concept or set of words that appealed to many: there is also a social and political context to its creation. Furthermore, even if a concept is marked by the context of its construction, even if it represents an undercourse of diverse discourses, it finishes by taking on its own life, its own autonomy, its own agency. A concept such as ES participates in the social construction of nature in both senses - as an ontological construction of nature and as a materialization of this construction. The concept travels, doing its work - which as we will see in the next two sections is often quite political work.

\section{From concept to practice: the devil in the details}

While ES appears as a 'natural' notion to the many interest coalitions and epistemic communities that adopt it, the way it actually works and gets applied in practice belies a variety of scientific or ecological complexities. As Robertson (2012) notes, the abstractions of ES to which humans assign value pass through several historical moments: classification, categorization, unbundling, and stacking. These complexities lead to choices that - whether they are implicitly or explicitly made - are political. They have different impacts on outcomes, and benefit certain groups or views more than others. In this section, we identify four different types of choices that bedevil the application of ES: (a) categorizing the services, (b) choosing the specific services to be analyzed, (c) delimiting the area - scale - to which the analysis applies, and (d) quantifying the analysis.

\subsection{Categorical consequences}

Simply the different ways of categorizing ES provokes debate. The four commonly used meta-categories promoted in the MEA (2005a)- provisioning, cultural, regulating, and supporting services - are awkward, for they crisscross ontological and epistemological barriers. Some include single-variable items that are easily measurable under a capitalist logic (e.g. timber production), others are more difficult, multivariate, complex 'services' informed by climatological or ecological theory (e.g. climate regulation), or different again, nonquantifiable conceptions and identities rooted in human experience (e.g. landscapes of ritual 
significance). Obviously, each classification scheme has its own purposes and uses, and these can be debated (Wallace, 2007; Costanza, 2008), but such transparency is often lacking.

The four ES categories hide a number of important distinctions that matter if humans use the concepts for policy decisions. First, they conflate indicators that are specifically services to humans with others that are better seen as indicators of ecosystem processes. These ecosystem processes (like soil formation, photosynthesis) provide resources to different functional groups - including humans (Jax, 2005) but are not directly appropriable nor useful to us. Not all the functions of ecosystems are ES for humans; they simply function. Second, no distinction is made between what is actually used by humans (i.e., the production of a cropland) or what can potentially be used, such as the capacity of an ecosystem for providing a defined service like water cleaning.Third, the categories hide the fact that humans play a role in creating or facilitating many services. Soils may be formed by earthworms and other soil engineers, bees may do pollination work, but humans also shape ecosystems, most obviously in agriculture. There are those aspects of ES that are inherent, and others which humans can manage, like in soils. For instance, Grimaldi et al. (2013) estimate that around $30 \%$ of the variation of soil ES in an Amazonian frontier are dependent on soil propriety, 30\% on farming practices and $40 \%$ on the interaction between farming practices and soil structure. Again, this raises the tensions elicited above about 'ecosystems' being a metaphor for largely natural systems, and the resulting downplaying of human stewardship roles aside from those involved in the conservation of natural areas. Focusing analyses only on the services produced in a 'natural' area - or on a farm - can lead to not 'seeing' the effects of, respectively, humans or natural processes on the services provided.

\subsection{Which service?}

Any ecosystem provides multitudes of services, yet the need for specific evidence and quantifiability (see below) typically constrains researchers and policymakers to address only a small selection of them. Fifty percent of studies on ES study one sole service, without considering other services or the interactions between them (Seppelt, 2011). Focusing on one service like this can hide other services, functions and characteristics of ecosystems, and can push policy and management recommendations towards maximizing only this service, with diverse consequences. As such, the choice of service is highly political. 
At its most obvious level, this can be illustrated by the preponderantfocus on carbon forecosystem service markets. Pushed by important policy objectives related to climate change, and facilitated by the relative ease of quantification, global attention focuses on particular ecosystems, like rainforests, that stock large amounts of carbon. Yet as the debate over REDD+ and similar policies has shown, this downplays other services that are important to local livelihoods, focuses attention only on certain types of ecosystems, all with the effect of reinforcing certain forms of poverty, inequality, and power relations (McAfee, 2012a).

Many authors have recognized the risk of focusing on single services. In particular, it has been recognized that there are 'trade-offs' between different services (Chisholm, 2012; de Groot et al., 2010; Martin-Lopez et al., 2012). A single ecosystem can produce food and fibers, clean water, and store carbon, among other things; and the efficiency of such services is increased by the interactions between these services. Nevertheless, some of these services are contradictory to one another, particularly if they are maximized. These antagonisms are obvious in the case of biodiversity versus intensive food production, or forest carbon storage versus beef production. Yet contradictions can also be observed within one category of services.Grimaldi et al. (2013) compared the supporting services of soils, soil chemical quality and soil plant-available water, both essential for food production. They showed that these services do not co-vary in thelandscape, and that one could be fulfilled while another was critically low. This means that when studies choose to measure one particular variable as representative of a broader service, it may not reflect the full picture.For instance, a study in Madagascar (Wendland et al., 2010) reduces 'water services' to water quality (as opposed to regulation or supply), and in turn reduce this to a predictive model of sediment-free water availability for drinking water, rice cultivation, and downstream mangroves). The same study, at a more general level, measures carbon, biodiversity, and water quality services, and considers productive services as an 'opportunity cost' and not a service (they measure they use is agricultural land rents). The impact, whether obvious or subtle, is that analyzing or measuring one ecosystem service over another (or one aspect of a particular ecosystem service over another) can fundamentally change how the services of a particular ecosystem or place are assessed. Grimaldiet al. (2013) show that in the Amazon, it is possible to justify, in the name of ES, either deforestation or conservation policies, depending on which services are included and the relative importance assigned.

\subsection{Scale}


Just as the choice of service has consequences, so does the choice of scale of analysis. What is the unit of analysis? The planet? Or is it a country,an ecosystem, a farm, a landscape, a specific forest plot,a particular species, or a category like invasive aliens (Pejchar and Mooney, 2009)? As Swift et al. (2004) note, the scale of analysis affects conclusions about ES. This is because certain aspects of each service are more prominent at different scales of measurement (e.g., remotely sensed pixels versus ecological transects), have benefits at different scales (e.g., soil carbon capture contributes to global climate mitigation but also to local soil-based 'supporting services' for a farmer), and are best managed at a human scale farm plots, forest stands - that tends to differ from the scale at which benefits are measured or accrued. This can lead to potentially biased conclusions and making comparisons tricky, if not impossible.

Climate regulation services through carbon sequestration are fundamentally measured globally (the amount of atmospheric carbon) and typically broken down by country or biome. Productive services like food and fiber production are typically assessed locally - at the crop field or farm level - and aggregated upwards. But even in these cases, the choice of analytical unit is highly contingent: farm scale makes sense for capitalist producers, but not for a community based management, for wildlife or for soil formation. A plot scale (i.e. the point at which the processes are measured) focuses more on biophysical processes. Each scale frames the processes and potential human management actions differently.

A scientific study ofES in Madagascar by Conservation International (Wendland et al., 2010) highlights a number of scale issues. The purpose of the study was to see if ES like biodiversity, water, and carbon could be "bundled" in order to maximize benefits to society more plainly, whether carbon offset payments could be justified as a means to fund biodiversity conservation or linked to additional water quality benefits. First, this study illustrates some of the technical issues underlying the analysis of ES. The study models carbon storage services (based on a global database), water quality services (reduced to supply of sediment-free water, as noted earlier), and biodiversity services (based on range and threat data for mammals, birds, and amphibians, including hand-drawn maps). Quantitative indicators of these services were created for each pixel in a grid covering the island. Each pixel measured roughly $1 \mathrm{~km}$ on a side. Data were re-sampled down from lower resolution data, or combined from higher resolution data, to fit this grid. The assumptions, multi-scale data sources, and data handling procedures lead to a number of limitations and caveats 
described by the authors that may affect the validity of the outcomes. Furthermore, global services (mitigation of atmospheric carbon) are mixed with very localized services (clean drinking water for a particular village) are unconditionally mixed in each pixel. Thus, the scale at which the phenomenon is measured and analyzed is the consequences of methodological choices.

Second, Wendland et al. make an interesting analytical decision about the scalar boundaries of their study.They limit their analysis only to those pixels containing Madagascar's remaining wetlands and forests, for "this is currently the main strategy used by international and national conservation organizations to target biodiversity priority areas" (p. 2094). Notwithstanding debates about whether these are the only areas of biodiversity value, this analytical choice predisposes the study to the finding that services exist in these areas. This is particularly so when (and this is the third point) the results are represented through particular scales (Rangan and Kull, 2009).Wendland et al. present their results on three national and one sub-national map.The impression given by these maps, which purport to show the distribution of 'multiple ES', is that ES just come from natural, biodiverse forests and wetlands, denying any potential role of other lands in these services, and downplaying (by not showing) other types of ES.They focus attention on the importance of Madagascar's 'wildlands' in need of conservation (in this case, through a carbon offset payment for ES program). This is unsurprising, given the affiliation of the authors with a conservation NGO.Methodological, analytical, and representational choices frame the findings in ways that support a particular set of politics on an island where the twin goals of environmental sustainability and social justice sometimes appear more contested than complementary (Corson, 2012; Keller, 2008; Pollini, 2011).

\subsection{Quantification}

There is an enormous pressure to quantify ES. Indeed, Costanza et al.'s (1997b, p. 253) seminal publication bluntly begins with the following sentence: "Because ecosystem services are not fully 'captured' in commercial markets or adequately quantified in terms comparable with economic services and manufactured capital, they are often given too little weight in policy decisions." Yet the quantitative measurement of most ES is far from straightforward (Schroth and McNeely, 2011), even for more readily quantifiable services like carbon sequestration (Canadell and Raupach, 2008). 
One consequence of the pressure for quantification is that it invites 'cherry picking' of the most accessible and measurable variables. The study we described earlier, Wendland et al. (2010, p. 2096) chose their variables because they are "the services where spatial data is easily attainable at the national scale". Likewise, when Pejchar and Mooney (2009, p. 502) review the cultural services and dis-services provided by invasive alien species, they emphasize recreation and tourism (quantified in terms of revenue) and aesthetics (quantified using the impact of frog decibels on property values). They do not go into detail on other cultural services, such as impacts on "inspiration, spirituality, religion, ceremony and tradition", because they "remain poorly studied, complex and difficult to quantify". The result of cherry-picking is a lop-sided, incomplete view of ES, privileging what can be counted and ignoring what cannot.

A second consequence is the need to combine multiple measures into aggregate numbers to facilitate comparison or use in markets. Creating a combined unit of measurement for ES as different as water cleaning, carbon storage or grain production contains many difficulties, both practical and ethical. As Robertson (2006, p. 382) notes in an analysis of wetland ES: "The difference between selling ecosystem services and selling loaves of bread is that legal and capital logics require information about ecosystem services that scientists cannot provide in an uncontroversial way." Any combined indicator reflects social choices.Even if each individual variable is measured using methods recognized in each sub-discipline, and the method of combining the variables is based on a statistical techniques, this kind of an equation reflects highly contingent and insufficiently explored choices.

The impact of quantification is that it can obscurescientific uncertainty and the political implications of how certain things are counted (or not) and calculated.Pressures towards finding quantifiable measures - which are by their nature more appropriate to some kinds of services than others - lead to increasingly technocratic approaches that hide the politics. It leads to a rule by bean-counters, as opposed to by leaders. We may have better and better numbers, but leaders are needed to debate which numbers matter and which things are innumerable.Making complexity legible - in this case through selective numbers - invites forms of political control and economic commodification that can have pernicious side effects (MacDonald and Corson, 2012; Robertson, 2012; Scott, 1998).

\section{Politics: impacts and opportunities}


ES are highly political. Who (or what) benefits from the concept, and who loses? What kinds of avenues are opened, which ones are closed? In this section, we investigate the impacts and opportunities created by the concept in a complex, multi-scalar world of social and governance interactions, particularly with respect to the proposed REDD policies under the Kyoto Protocol. We first trace, based on the literature, the 'in principle' and somewhat blackand-white readings of 'winners' and 'losers' in what can be a very polarized debate. Then we draw on brief case studies in Madagascar and particularly Brazil to look at the complex gray areas that may be opened by the concept.

\subsection{In principle}

The confluence of interest between ecology and economics that is embodied in ES is meant to create a number of 'winners'. First, ecosystems that are protected because they are properly valued. Second, environmental governance is meant to benefit, for it becomes more efficient under a (neo)liberal regime. Third, people win, for they benefit from the ES provided. And finally, the service owners benefit from the application of ES, for they can charge for the delivery of these services - and given the geography of ES, these could often be otherwise marginalized rural and/or indigenous people.

REDD is often touted as a good example of such policy. The avoidance of additional carbon emissions from deforestation that would have happened without the policy provides a global service: the mitigation of climate change. It does so, it is argued, more cost effectively than other emissions reduction scenarios. Furthermore, it benefits other, more local ES - watershed protection, biodiversity - and can be a source of sustainable financing for rural communities in developing countries.

Yet many critiques have been laid at ES in general, or REDD in particular - about winners not winning, about losers that are not mentioned, about collateral damage, or about missed alternatives and ideological consequences. Three themes stand out. First, critiques from a political economic angle see ES as creating new spaces of capitalist accumulation out of formerly common and/or public goods. They point out the irony of capitalism being harnessed to rectify the very problems it creates, and the critique the way in which the process reifies dominant power relations and creates exclusions (Bumpus and Liverman, 2011; Corson and MacDonald, 2012; McAfee, 2012b). Second, the urgency of implementation, its top-down 
inspiration, and the size and strength of the finances involved are criticized for reversing some of the gains in decentralizing natural resource management. That is, instead of empowering rural managers, programs like REDD lead to a loss of local or community control (Phelps et al., 2010). Third, the use of ESpresumes a certain kind of interaction with the environment, and pushes to the sidelines other approaches to environmental management, whether regulatory, stewardship, or spiritual (Turnhout et al., 2013).

\subsection{In practice}

A jaded view might note that the real winners of ES are the experts hired to produce reports, evaluations, and projects. More prosaically, however, it behooves us to note the complexity of impacts and uses of ES by multiple actors at diverse scales and in varied social contexts. There is, as Pirard and Broughton (2011, p. 1) note, a remarkable heterogeneity in the mechanisms lumped under 'market-based instruments' (including payments for ES), and they only have 'loose links to markets as defined by economic theory' but instead close ties to legal frameworks and public policy. ES are being used, together with other market-based instruments, for agendas not easily glossed as neoliberalization, indeed, they"significantly exceed conventional versions of neoliberalim both in the diversity of their empirical forms and in the polyphony of theoretical justifications and foundational principles" (Dempsey and Robertson, 2012, p. 773). In other words, there is serious complexity and messiness in carbon markets.These conclusions are consistent with what we observed in concrete situations. When being applied, ESis used to justify policies broadly favorable to nature conservation, but the specific agenda of these arguments highly depends on the specific political, ecological, and historical context - which actors, which country, at what scale.

This becomes evident when investigating the implementation of REDD and other payment for ES programs in tropical rainforest countries. At a global level, rainforests are mainly seen as carbon traps (Bidaud, 2011; Moolna, 2012). Locally and regionally, of course, rainforests (and cleared rainforest lands) provide diverse other services, from food production to nutrient cycling. At a national level, and from the point of view of national governments, there is strong interest in forests as an income source, and many governments lobbied strongly for REDD and other programs in order to bring these income streams to their country (to augment or replace logging income) and to finance sustainable development and conservation (Angelsen et al., 2009).But the way they do so is extremely diverse - here we contrast Madagascar with multiple administrative scales in Brazil. 
In Madagascar, ES in general, and REDD in particular, are mobilized mainly to justify and finance the conservation or preservation of biodiversity in more 'natural' landscapes. The policies have the support of the national government, but are largely initiated and implemented by international actors from development agencies and conservation organizations in what has been called a 'governance state' (Duffy, 2006). The result has been five pilot projects, some operating in multiple locations, addressing forest conservation in zones varying from 2000 to 372,000 hectares through carbon offset funds from overseas (Bidaud, 2011; Ferguson, 2009; Pollini, 2009; Rakotoarijaona, 2012).

Brazil, home to the lion's share of the Amazonian rainforest,provides a starkly different example. The dramatic decrease in deforestation rates since 2006 is attributed to increased productivity in the Cerrado region (Brown, 2013)and to command and control policies (Dalla Nora, 2013). This result obviates a need for REDD funds. Yet the federal government still usesES to justify policies, but tellingly not directly for conservation, but instead in the agricultural and in the social sectors. One program, ProAmbiente, aimed to pay small-scale farmers for adopting less aggressive practices in the rural Amazon. This program is embedded in local relationships and politics, particularly with respect to the defense of the idea of small scale family farming and the lobbying of the family farm trade unions(Arnauld de Sartre and Berdoulay, 2011). Another program, Bolsa verde, is oriented toward poor families living in protected area who are granted of $100 \$$ a month to compensate the loss of income due to the protected area. These policies are not based on measurements of services, but on an acknowledgement of the importance of agricultural practices or protected areas to the environment.

Brazilian states are more interested inES based policies. In Amazonas, a large program of payment for environmental servicesis dedicated to protected areas. It is composed of four different subprograms that fund social infrastructures, associations, productive activities or families. Families living in protected areas can receive income supplements of up to $25 \$$ a month for engaging themselves in practices favorable to nature conservation The program is funded through a partnership between the federal government (through the Fundo Amazonia), the state, and various private actors (BradescoBank, Coca Cola, MariottInternational, Samsung, HRT, Tam). Such policies have been chosen by many other Brazilian states, leading to a conflict between the federal government, which does not want and need PES 
policies, and local governments. President Lula's positions favorable to REDD at the Copenhagen forum was - against his federal interests - strongly shaped by these States (Aubertin, 2012).

To conclude, ES creates winners and losers, but one cannot be categorical about how this concept plays out in different contexts. Even if, in general, the concept of ES has largely served to give rhetorical weight and new tools to those who seek to conserve biodiversity, it has also been harnessed - as we show for Brazil - to justify public policies focused on social welfare or farm support. It has not found a major place in formal markets (c.f. Dempsey and Roberston, 2012).

\section{Conclusion}

Following a political ecology framework, we have investigated the origin and agency of the 'ecosystem services' idea, its relationship to multi-scale power structures that constrain or facilitate certain outcomes, the practical 'on-the-ground' contextual difficulties of applying the idea, and its impacts for different parts of society and different components of the environment. The concept is simultaneously a pedagogic, heuristic, policy (technical) and political notion. When it serves to reinforce the idea that humans are dependent on ecosystems, it is pedagogical. When scientists use it to have a different gaze on the environment, it has a heuristic function. When it is used to justify conservation, social or agricultural policies, it is a policy-framing notion. And when it helps to solve conflicts or to engage different actors with one another, it is a political notion.

The ESconcept is a buzzword, a boundary object with widespread appeal, and is used in diverse ways by different interests to justify different kinds of interventions that at times might be totally opposed.As a powerful concept, it must be engaged with. It lies behind, or contributes to, the idea of a 'green economy' that featured so prominently in the Rio +20 meeting in $2012 .^{8}$ Yet, it is important to remember that many choices are made in selecting

\footnotetext{
${ }^{8}$ Somewhat ironically, 'ecosystem services' as a term itself did not feature prominently at Rio +20 , and was absent from the final Declaration.So its crowning moment in the MEA perhaps also marked its apogee - though it is prominent in the IPBES (Intergovernmental Platform on Biodiversity and Ecosystem Services) launched by the United Nations in 2012. Citation analyses show that citations to 'ecosystem services' were lower in the decade after the MEA compared to the decade before the MEA for the founding disciplines of ecology and economy, but that the concept lives on strongly in applied disciplines like conservation biology and environmental management (authors, unpublished material).
} 
and applying an ES concept to the management of soils, vegetation, water, and atmosphere: choices about how problems are framed, choices over networks of actors that are elicited, choices over how the idea is implemented. While each choice usually makes sense within its own logic, they remain choices. They make ES political (Rangan and Kull 2009).It opens some doors, closes some others. While ES has mainly been harnessed to justify and finance a biodiversity conservation agenda, we have seen that it has been appropriated by other actors notably indigenous activists and family farming lobbies in Brazil - as a discourse to further other agendas.

ES as a concept, discourse, and practice results of intertwined power relationships, pragmatism, and adhesion to shared values of other (and larger) consensuses around biodiversity and neoliberal policies. The availability of capital, particularly in a neoliberal dosomething-about-climate-change world, has been important factor in sustaining the idea. Yet these consensuses are certainly not shared by all, or understood in the same way, so it is important to trace the overlaps and contradictions of different epistemic communities and how they become expressed through political processes in particular countries and regional contexts.

Political ecologists have long asserted that environmental change is not just a scientific or technical phenomenon, but fundamentally social. ES as a concept is a perfect illustration of this - couched in the phrases of scientific certainty, the concept facilitates certain types of interventions and discussions that reflect particular discourses, power relations, and politicaleconomic structures, even if, at times, it is somewhat subverted as we saw in the Brazil case. Yet ES's real utility is not in asking or answering the questions that societiesmust ask when debating resource management policies and actions. ES does not resolve questions of winners and losers, trade-offs, and who has the right to decide and the might to enforce. It is, however, well placed to provide evidence that informs these social and political decisions - this plot of trees sequesters $\mathrm{X}$ tons of carbon; this valley is habitat for $\mathrm{Y}$ families of mammals; this forest supports the livelihood needs of $\mathrm{Z}$ families. Human societies are usually well equipped to deal with such decisions, even in polarized debates in which compromise appears intractable. That is what the political arena is for - legislators, agencies, and private actors propose and undertake different stances and activities, interest groups complain and lobby, debate takes place, and a resolution is reached. 


\section{Acknowledgements}

The work of MC and XAS is supported by ANR-AGES. The Université de Pau et des Pays de l'Adour funded research collaboration with CAK. We gratefully acknowledge the constructive comments of colleagues and collaborators along the way.

\section{References}

Agrawal, A., 2005. Environmentality. Duke University Press, Durham.

Angelsen, A., Brockhaus, M., Kanninen, M., Sills, E., Sunderlin, W.D., Wertz-Kanounnikoff, S., 2009. Realising REDD+: national strategy and policy options. Center for International Forestry Research (CIFOR), Bogor (Indonesia).

Arnauld de Sartre, X., Berdoulay, V., 2011. Des politiques territoriales durables ? Leçons d'Amazonie. Éditions Quae, Clermont-Ferrand.

Arsel, M., Büscher, B., 2012. Nature ${ }^{\mathrm{TM}}$ Inc.: Changes and Continuities in Neoliberal Conservation and Market-basedEnvironmental Policy. Development and change 43 (1), 53-78.

Aubertin C., 2012, Repenser le développement du monde: Le Brésil se met en scène à RIO+20, Mouvements, 70, 41-56

Bakker, K., 2010. The limits of 'neoliberal natures': Debating green neoliberalism. Progress in Human Geography 34 (6), 715-735.

Barnaud, C., Antona, M., Marzin, J., 2011.Vers une mise en débat des incertitudes associées à la notion de service écosystémique. VertigO, 11 (1), http://vertigo.revues.org/10905

Barry, A., Osborne, T., Rose, N., 1996. Foucault and Political Reason. University of Chicago Press, Chicago.

Batterbury, S.P.J., Horowitz, L., 2013. Engaged Political Ecology. Open Book Publishers, Cambridge.

Bidaud, C., 2011. Le carbone qui cache la forêt. La construction scientifique et la mise en politique du service de stockage du carbone des forêts malgaches. Université de Genève, Genève.

Boyd, J., Banzhaf, S., 2007. What are ecosystem services? The need for standardized environmental accounting units. Ecological Economics 63 (2-3), 616-626.

Brenner, N., Peck, J., Theodore, N., 2010. Variegated neoliberalization: geographies, modalities, pathways. Global Networks 10 (2), 182-222.

Brockington, D., 2011. Ecosystem services and fictitious commodities. Environmental Conservation 38 (4), 367-369.

Brown, J.C. 2013, The Borlaug Hypothesis and Agricultural Intensification in MatoGrosso, Brazil.Annual Meeting of the Association of American Geographers, Los Angeles, 2013

Bumpus, A.G., Liverman, D.M., 2011. Carbon colonialism? Offsets, greenhouse gas reductions and sustainable development in: Peet, R., Robbins, P., Watts, M. (Eds.), Global Political Ecology. Routledge, London, pp. 203-224.

Buttel, F.H., 2000. Ecological modernization as social theory.Geoforum 31, 57-65.

Callicott, J.B., Crowder, L.B., Mumford, K., 1999. Current normative concepts in conservation. Conservation Biology 13 (1), 22-35.

Canadell, J.G., Raupach, M.R., 2008. Managing forests for climate change mitigation. Science 320 (5882), 1456-1457.

Castree, N., 2008.Neoliberalising nature: the logics of deregulation and reregulation. Environment and Planning A 40 (1), 131-152. 
Castree, N., Braun, B., 2001. Social Nature. Blackwell, Malden, MA.

Castro, M., Ollivier, G., 2012. Politicalecology des discours environnementaux internationaux : le cas de l'approche par écosystème de la Convention sur la diversité biologique (CBD), in: Gautier, D., Benjaminsen, T.A. (Eds.), Environnement, discours et pouvoir: l'approche Politicalecology. ÉditionsQuæ, Versailles, pp. 87-110.

Chan, K.M.A., Satterfield, T., Goldstein, J., 2012. Rethinking ecosystem services to better address and navigate cultural values. Ecological Economics 74 (0), 8-18.

Chisholm, R.A., Wintle, B.A., 2012. Choosing ecosystem service investments that are robust to uncertainty across multiple parameters. Ecological Applications 22 (2), 697-704.

Cohen, A., 2012. Rescaling environmental governance: watersheds as boundary objects at the intersection of science, neoliberalism, and participation. Environment and Planning A 44 (9), 2207-2224.

Corbera, E., Brown, K., Adger, W.N., 2007. The equity and legitimacy of markets for ecosystem services. Development and Change 38 (4), 587-613.

Corson, C., 2012. From rhetoric to practice: how high profile politics impeded community consultation in Madagascar's new protected areas. Society and Natural Resources 25, 336-351.

Corson, C., MacDonald, K.I., 2012. Enclosing the global commons: the convention on biological diversity and green grabbing. Journal of Peasant Studies 39 (2), 263-283.

Costanza, R., 2008. Ecosystem services: multiple classification systems are needed. Biological Conservation 141, 350-352.

Costanza, R., Cumberland, J., Daly, H., Goodland, R., Norgaard, R.B., 1997a.An Introduction to Ecological Economics. St. Lucie Press, Boca Ratan, Florida.

Costanza, R., d'Arge, R., de Groot, R., Farber, S., Grasso, M., Hannon, B., Limburg, K., Naeem, S., O'Neill, R.V., Paruelo, J., Raskin, R.G., Sutton, P., van den Belt, M., 1997b.The value of the world's ecosystem services and natural capital. Nature 387, 253260.

Cronon, W., 1996. Uncommon Ground. W. W. Norton, New York.

Daily, G.C., 1997. Nature's services: societal dependence on natural ecosystems. Island Press, Washington.

Eloi Lennon Dalla-Nora, E.L., Dutra de Aguiar, A.P., Montenegro Lapola, D. 2013, Global economy or regional governance? What are the actual drivers of Amazon deforestation?Annual Meeting of the Association of American Geographers, Los Angeles, 2013

Daw, T., Brown, K., Rosendo, S., Pomeroy, R., 2011. Applying the ecosystem services concept to poverty alleviation: the need to disaggregate human well-being. Environmental Conservation 38 (4), 370-379.

de Groot, R.S., Alkemade, R., Braat, L., Hein, L., Willemen, L., 2010. Challenges in integrating the concept of ecosystem services and values in landscape planning, management and decision making. Ecological Complexity 7 (3), 260-272.

Demeritt, D., 2001. The construction of global warming and the politics of science. Annals of the Association of American Geographers 91 (2), 307-337.

Demeritt, D., 2002. What is the 'social construction of nature'? A typology and sympathetic critique. Progress in Human Geography 26 (6), 767-790.

Dempsey, J., Robertson, M.M., 2012. Ecosystem services: Tensions, impurities, and points of engagement within neoliberalism. Progress in Human Geography 36 (6), 758-779.

Dressler, W., 2013. Green governmentality and swidden decline on Palawan Island. Transactions of the Institute of British Geographers, 10.1111/tran.12026. 
Duffy, R., 2006. Non-governmental organisations and governance states: the impact of transnational environmental management networks in Madagascar. Environmental Politics 15 (5), 731-749.

Ernstson H., Sörlin S., 2013. Ecosystem services as technology of globalization: on articulating values in urban nature. Ecological Economics, 86, 274-284.

Fairhead, J., Leach, M., Scoones, I., 2012. Green grabbing: a new appropriation of nature? The Journal of Peasant Studies 39 (2), 237-261.

Farnham, T. J. 2007. Saving Nature's Legacy: Origins of the Idea of Biological Diversity. Yale University Press, New Haven.

Ferguson, B., 2009. REDD comes into fashion in Madagascar. Madagascar Conservation and Development 4 (2), 132-137.

Ferguson, J., 1994. The Anti-Politics Machine. University of Minnesota Press, Minneapolis.

Fisher, B., Turner, R.K., Morling, P., 2009. Defining and classifying ecosystem services for decision making. Ecological Economics 68 (3), 643-653.

Forsyth, T., 2003.Critical Political Ecology. Routledge, London.

Forsyth, T., 2005. The political ecology of the ecosystem approach for forests, in: Sayer, J., Maginnis, S. (Eds.), Forests in landscapes: ecosystem approaches for sustainability. Earthscan, London, pp. 165-176.

Gautier, D., Benjaminsen, T.A., 2012. Environnement, discours et pouvoir:l'approche Politicalecology. ÉditionsQuæ, Versailles.

Ginn, F., and D. Demeritt. 2009. Nature: a contested concept. Pages 300-311 in N. Clifford, S. Holloway, S. P. Rice, and G. Valentine, editors.Key Concepts in Geography.Sage, London.

Goffman, E., 1974. Frame analysis. Harper and Row, London.

Gómez-Baggethun, E., de Groot, R., Lomas, P.L., Montes, C., 2010. The history of ecosystem services in economic theory and practice: From early notions to markets and payment schemes. Ecological Economics 69 (6), 1209-1218.

Gómez-Baggethun, E., Ruiz, J.P., 2011.Economic valuation and the commodification of ecosystem services. Progress in Physical Geography 35 (5), 613-628.

GrimaldiM., Oszwald J., DolédecS., Hurtado M.P., Miranda I.S., Arnauld de Sartre X., Santos de AssisW., CastañedaE., Desjardins T., Dubs F., Guevara E., GondV., Santana Lima T.T., MarichalR., MichelottiF., MitjaD., Noronha N. Cornejo, D.O.Nascimento, M. Ramirez B., Rodriguez G., SarrazinM., Lopes da Silva M., Silva Costa L.G., Lindoso de Souza S., VeigaI.P. Jr, Velasquez E., Lavelle P., 2013.Ecosystem services in Amazonian pioneer fronts: Searching for landscape drivers, Landscape Ecology, in press.

Heynen, N., Robbins, P., 2005. The neoliberalization of nature: governance, privatization, enclosure and valuation. Capitalism Nature Socialism 16 (1), 5-8.

Jax, K., 2005, Function and "functioning'" in ecology: what does it mean? Oikos 111 (3), 641-648.

Johnston, R.J., Russell, M., 2011.An operational structure for clarity in ecosystem service values. Ecological Economics 70 (12), 2243-2249.

Kates, R. W., T. M. Parris, and A. A. Leiserowitz. 2005. What is sustainable development?Goals, indicators, values, and practice. Environment 47:8-21.

Keller, E., 2008. The banana plant and the moon: conservation and the Malagasy ethos of life in Masoala, Madagascar. American Ethnologist 35 (4), 650-664.

Kumar, P., 2012. TEEB Ecological and Economic Foundations, in: Sukhdev, P. (Ed.), The Economics of Ecosystems and Biodiversity - TEEB. Routledge, p. 456. 
Lamarque, P., Quétier, F., Lavorel, S., 2011. The diversity of the ecosystem services concept and its implications for their assessment and management. ComptesRendusBiologie 334 (5-6), 441-449.

Lant, C.L., Ruhl, J.B., Kraft, S.E., 2008. The tragedy of ecosystem services.BioScience 58 (10), 969-974.

Larson, B.M.H., 2011. Metaphors for Environmental Sustainability. Yale University Press, New Haven.

Leach, M., Mearns, R., 1996. The Lie of the Land:Challenging Received Wisdom on the African Environment. Heinemann, Portsmouth, NH.

Lélé, S.M., 1991. Sustainable development:a critical review. World Development 19 (6), 607 621.

MacDonald, K.I., Corson, C., 2012. 'TEEB begins now': a virtual moment in the production of natural capital. Development and Change 43 (1), 159-184.

Martin-Lopez, B., Iniesta-Arandia, I., Garcia-Llorente, M., Palomo, I., Casado-Arzuaga, I., Del Amo, D.G., Gomez-Baggethun, E., Oteros-Rozas, E., Palacios-Agundez, I., Willaarts, B., Gonzalez, J.A., Santos-Martin, F., Onaindia, M., Lopez-Santiago, C., Montes, C., 2012. Uncovering Ecosystem Service Bundles through Social Preferences. PLoS One 7 (6).

McAfee, K., 1999. Selling nature to save it?Biodiversity and the rise of green developmentalism. Environment and Planning D: Society and Space 17 (2), 133-154.

McAfee, K., 2012a. Nature in the market-world: ecosystem services and inequality. Development 55 (1), 25-33.

McAfee, K., 2012b. The contradictory logic of global ecosystem services markets. Development and Change 43 (1), 105-131.

McCarthy, J., Prudham, S., 2004. Neoliberal nature and the nature of neoliberalism.Geoforum 35 (3), 275-283.

McElwee, P.D., 2012. Payments for environmental services as neoliberal market-based forest conservation in Vietnam: Panacea or problem? Geoforum 43 (3), 412-426.

MEA (Millennium Ecosystem Assessment), 2005a. Ecosystems and Human Well-being: Synthesis. Island Press, Washington DC.

MEA (Millennium Ecosystem Assessment), 2005b. Ecosystems and Human Well-being: Biodiversity Synthesis. Island Press, Washington DC.

Mitchell, R.B., Clark, W.C., Cash, D.W., Dickson, N.M., 2006.Global Environmental Assessments. MIT Press, Cambridge.

Mol, A.P.J., Sonnenfeld, D.A., Spaargaren, G., 2009.The Ecological Modernisation Reader. Routledge, London.

Moolna, A., 2012. Making Sense of CO2: Putting Carbon in Context. Global Environmental Politics 12 (1), 1-7.

Nahlik, A.M., Kentula, M.E., Fennessy, M.S., Landers, D.H., 2012. Where is the consensus? A proposed foundation for moving ecosystem service concepts into practice. Ecological Economics 77 (0), 27-35.

Norgaard, R.B., 2010. Ecosystem services: From eye-opening metaphor to complexity blinder. Ecological Economics 69 (6), 1219-1227.

O'Neill, R.V., 2001. Is it time to bury the ecosystem concept?(With full military honours, of course!). Ecology 82 (12), 3275-3284.

Pearce, D. 1993.Economic Values and the Natural World.Earthscan, London.

Peet, R., Watts, M., 1996. Liberation Ecologies. Routledge, London.

Pejchar, L., Mooney, H.A., 2009. Invasive species, ecosystem services and human well-being. Trends in Ecology \& Evolution 24 (9), 497-504. 
Peluso, N.L., Vandergeest, P., 2001. Genealogies of the political forest and customary rights in Indonesia, Malaysia, and Thailand.The Journal of Asian Studies 60 (3), 761-812.

Pesche, D., 2011. Le Millennium Ecosystem Assessment : Evaluations globales et circulation des idées dans la production des politiques, Programme Serena Document de travail no 2011-12, Montpellier.

Peterson, M.J., Hall, D.M., Feldpausch-Parker, A.M., Peterson, T.R., 2009. Obscuring Ecosystem Function with Application of the Ecosystem Services Concept. Conservation Biology 24 (1), 113-119.

Phelps, J., Webb, E.L., Agrawal, A., 2010. Does REDD+ threaten to recentralize forest governance? Science 328, 312-313.

Pigou, A.C., 1920, The Economics of Welfare.Macmillan, London.

Pirard, R., Broughton, E., 2011. What's in a name? Market-based instruments for biodiversity. IDDRI Synthèses 11 (1), 1-4.

Pollini, J., 2009. Carbon sequestration for linking conservation and rural development in Madagascar: the case of the Vohidrazana-Mantadia Corridor Restoration and Conservation Carbon Project. Journal of Sustainable Forestry 28 (3), 322-342.

Pollini, J., 2011. The difficult reconciliation of conservation and development objectives: the case of the Malagasy Environmental Action Plan. HumanOrganization 70 (1), 74-87.

Rakotoarijaona, J.R., 2012. L'environnement pour le développement?Une analyse de la REDD, in: RakotoRamiarantsoa, H., Blanc-Pamard, C., Pinton, F. (Eds.), Géopolitique et environnement. Les leçons de l'expérience malgache. IRD Éditions, Marseille, pp. 247-266.

Rangan, H., Kull, C.A., 2009. What makes ecology 'political'?: rethinking 'scale' in political ecology. Progress in Human Geography 33 (1), 28-45.

Robbins, P., 2001. Fixed categories in a portable landscape:the causes and consequences of land cover categorization. Environment and Planning A 33, 161-179.

Robbins, P., 2007. Lawn People:How Grasses, Weeds, and Chemicals Make Us Who We Are. Temple University Press, Philadelphia.

Robbins, P., 2012. Political Ecology:A Critical Introduction (2nd ed), 2nd ed. Wiley, Oxford.

Robertson, M.M., 2006. The nature that capital can see: science, state, and market in the commodification of ecosystem services. Environment and Planning D: Society and Space 24, 367-387.

Roth, R.J., Dressler, W., 2012. Market-oriented conservation governance: The particularities of place. Geoforum 43 (3), 363-366.

Schroth, G., McNeely, J.A., 2011. Biodiversity conservation, ecosystem services and livelihoods in tropical landscapes: towards a common agenda. Environmental Management 48, 229-236.

Scott, J.C., 1998. Seeing Like a State. Yale University Press, New Haven.

Seppelt, R., Dormann, C.F., Eppink, F.V., Lautenbach, S., Schmidt, S., 2011. A quantitative review of ecosystem service studies: approaches, shortcomings and the road ahead. Journal of Applied Ecology 48 (3), 630-636.

Star, S. L., Griesemer, J.R. 1989. Institutional ecology, 'translations' and boundary objects: Amateurs and professionals in Berkeley's Museum of Vertebrate Zoology, 1907-39. Social Studies of Science 19 (3), 387 -420.

Swift, M.J., Izac, A.M.N., van Noordwijk, M., 2004. Biodiversity and ecosystem services in agricultural landscapes: are we asking the right questions? Agriculture, Ecosystems\&Environment 104 (1), 113-134.

Tassin, J., 2012. Un agrosystème est-il un écosystème? Cahiers Agriculture 21, 57-63.

Tassin, J., Kull, C.A., 2012. Pour une autre représentation métaphorique des invasions biologiques. Natures Sciences Sociétés 20 (4), 404-414. 
Turnhout, E., Waterton, C., Neves, K., Buizer, M., 2013. Rethinking biodiversity: from goods and services to "living with". Conservation Letters 6 (3), 154-161.

Van Hecken, G., Bastiaensen, J., 2010. Payments for ecosystem services: Justified or not? A political view. Environmental Science and Policy 13 (8), 785-792.

Wallace, K.J., 2007. Classification of ecosystem services: problems and solutions. Biological Conservation 139, 235-246.

Wendland, K.J., Honzák, M., Portela, R., Vitale, B., Rubinoff, S., Randrianarisoa, J., 2010. Targeting and implementing payments for ecosystem services: Opportunities for bundling biodiversity conservation with carbon and water services in Madagascar. Ecological Economics 69 (11), 2093-2107.

Williams, R. 1983. Keywords. Fontana, London.

Wilson, E. O., editor. 1988. Biodiversity. National Academy Press, Washington.

$\mathrm{Xu}, \mathrm{L}$. , Marinova, D., 2013. Resilience thinking: a bibliometric analysis of socio-ecological research. Scientometrics, DOI 10.1007/s11192-11013-10957-11190.

Zbinden, S., Lee, D.R., 2005. Paying for environmental services: an analysis of participation in Costa Rica's PSA program. World Development 33 (2), 255-272. 